\title{
Nasalization of the Initial Consonant (d-) of the Present Perfect Tense Marker (-dẹ) After the Main Verb in Ịzọn: A Case Study of the Tarakiri Dialect
}

\author{
God'spower Tamaraukuro Prezi \\ Niger Delta University, Wilberforce Island, Nigeria
}

\begin{abstract}
In Ịzọn, as in Akan and Edo, nasalization is distinctive, because it brings about a change in meaning as in: /su/

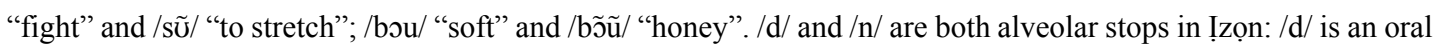
stop, while $/ \mathrm{n} /$ is a nasal stop. Also, while /d/ is a voiced alveolar plosive, $/ \mathrm{n} /$ is an (voiced) alveolar nasal. This means, in effect, that the two consonants $(/ \mathrm{d} /$ and $/ \mathrm{n} /)$ are homorganic in İọn, because they are made at the same place of articulation and with the same articulators. However, in many verbs, whose present perfect tenses are represented by -dẹ in the Tarakiri dialect of İzọn, the -dẹ is changed to -nẹ after the main verb. That is, in phonological terms, /d/ rewrites as $/ \mathrm{n} /$ in the environment after a syllable consisting of a nasal consonant or a nasalized vowel, i.e., $[+$ voice + alveolar + plosive $]$ becomes $[+$ alveolar + nasal $]$ after $[+$ nasal $]$. This paper looks at, describes, and examines this phonological process/phenomenon of the replacement of an oral stop by a nasal stop after a syllable consisting of a nasal consonant or a nasalized vowel.
\end{abstract}

Keywords: İzọn, Tarakiri, homorganic, nasal, nasalization, -dẹ, -nẹ, assimilation

\section{Introduction}

\section{A Brief Introduction to İzọn}

İọn is the major one of the Ijoid group of languages spoken in the Niger Delta Region and the South-South geo-political zone of Nigeria. Izọn is spoken in Bayelsa, Delta, Edo, Ondo, and Rivers State of Nigeria.

\section{Tarakiri Clan}

The following towns make up the Tarakiri clan: Agbere, Ebẹdẹbiri, Tọrụ-Orua, Bulou-Orua, Angalabiri, Ofoni, Oduofori, Adọbụ, Odurubu, Anyama, Oweikorogha, Egeibiri, Ozezebiri, Obololi, Ayamasa, Isampọu, and Egbemọ-Angalabiri. Tarakiri is a dialect of Ịzọn spoken in these communities.

The term nasality has been defined by various scholars. Among them is Childs (2000, p. 1), who used "nasality" to refer to both the feature [nasal] in segments and to nasalization processes. In İọn, nasality (as a feature) differentiates nasal stops, e.g., /m, n, y/ from voiced stops, e.g., /p, b, t, d, k, g, kp, gb/. Izọn also has vowel nasalization, which is the spread of nasality onto vowels from nasal segments in adjacent positions.

In İọn, as in many West African languages, nasality plays a major role in the sound system and grammar.

God'spower Tamaraukuro Prezi, lecturer, Department of English and Literary Studies, Faculty of Arts, Niger Delta University. 
Nasality in İọn is realized both phonetically and phonologically on both consonants and vowels. However, in this paper, the author is looking at the phonological process of the nasalization of the morpheme-initial consonant in the realization of the İọn immediate past tense marker (Williamson, 1991, pp. 149-150) which is the equivalent of the English present perfect tense, from a Tarakiri perspective.

According to Atóyèbí (1999):

Among the West Benue-Congo languages, only Òkọ and a few Southern Edoid dialects, Uvwie and Agbon (Urhobo) and the Delta Edo dialect, Epie (Williamson, 1973, p. 128), have a vowel system in which all the oral vowels have a corresponding nasalized counterpart. (p. 1)

This is not entirely true, as in İọn also, all the oral vowels have corresponding nasalized counterparts.

\section{The Vowels of İọn}

Oral vowels. Izọn has nine phonemic oral vowels. There is vowel harmony of the eight non-low vowels. The low vowel /a/ is neutral to vowel harmony as it can co-occur with either set of vowels. The wide vowels and the narrow do not normally go together in a simple word (see Table 1).

Oral vowels:

$$
\begin{array}{ll}
\text { a e i o u } & \text { set of wide vowels } \\
\text { ẹ ị ọ ụ } & \text { set of narrow vowels }
\end{array}
$$

\begin{tabular}{|c|c|c|c|c|}
\hline No. & Phoneme & Orthography & Example in Ịzọn & English gloss \\
\hline 1 & $/ \mathrm{a} /$ & $\mathrm{a}$ & agurá & "star" \\
\hline 2 & $/ \mathrm{e} /$ & $\mathrm{e}$ & esé & "trouble" \\
\hline 3 & $/ \varepsilon /$ & ẹ & arẹe & "name" \\
\hline 4 & /i/ & $\mathrm{i}$ & dírí & "medicine" \\
\hline 5 & $/ \mathrm{I} /$ & $i$ & ịgịná & "pepper" \\
\hline 6 & $/ \mathrm{o} /$ & 0 & ogbóó & "land" or "union" \\
\hline 7 & $/ \mathrm{p} / ; / \mathrm{J} /$ & $\underline{0}$ & lọ́sị & "head gear" \\
\hline 8 & $/ \mathrm{u} /$ & $\mathrm{u}$ & buru & "yam" \\
\hline 9 & $/ \mathrm{U} /$ & $\underline{\varphi}$ & fụrụ́ & "smell" \\
\hline
\end{tabular}

Table 1

The Oral Vowels of Izon

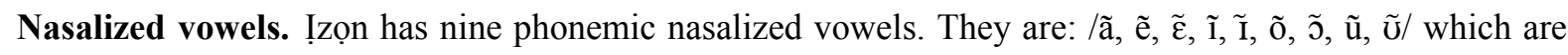
represented orthographically as: ã, ẽ, ẹ, ĩ, ị, õ, ọ, ũ, ụ. When a vowel occurs in a nasal environment, the vowel becomes nasalized. When two vowels occur in a word before the final $/ \mathrm{n} /$, both are affected by the nasalization. Usually, in the orthography, nasalization is marked by writing the consonant " $n$ " at the end of the syllable after

\begin{tabular}{|c|c|c|c|c|}
\hline No. & Phoneme & Orthography & Example in İọn & English gloss \\
\hline 1 & $/ \tilde{\mathrm{a}} /$ & $\tilde{a}$ & $\begin{array}{l}\text { tấn } \\
\text { sấn }\end{array}$ & $\begin{array}{l}\text { "to gather" } \\
\text { "to urinate" }\end{array}$ \\
\hline 2 & $/ \tilde{\mathrm{e}} /$ & $\tilde{\mathrm{e}}$ & egẽni & “visitor" \\
\hline 3 & $/ \tilde{\varepsilon} /$ & ệ & sẹén & "shave" \\
\hline 4 & $/ \tilde{\mathbf{1}} /$ & $\tilde{1}$ & $\sin$ & "to vomit" \\
\hline
\end{tabular}
the vowel as illustrated in Table 2 .

Table 2

Izon Distinguishes Between Oral Vowels and Nasalized Vowels (Agbegha, Prezi, Tarilayefa, \& Prezi, 2011, p. 3) 
(Table 2 continued)

\begin{tabular}{|c|c|c|c|c|}
\hline No. & Phoneme & Orthography & Example in Ịzọn & English gloss \\
\hline 5 & $\pi /$ & $\tilde{\ddot{i}}$ & tịn & "tree" \\
\hline 6 & $/ \tilde{\mathbf{o}} /$ & $\tilde{0}$ & ondó & "to last long" \\
\hline 7 & $/ \tilde{\mathbf{z}} /$ & $\tilde{o}$ & kọn & "to take" \\
\hline 8 & $/ \tilde{\mathrm{u}} /$ & $\tilde{\mathrm{u}}$ & fun & "book" \\
\hline 9 & $/ \tilde{\mathrm{u}} /$ & $\tilde{u}$ & sụn & "stretch" \\
\hline
\end{tabular}

\section{Nasalization}

Nasalization is a secondary modification which involves the superimposition of a lowered velum, adding a nasal resonance to the production of an oral sound. When the soft palate or velum is lowered, it allows air to pass out through the nose thereby forming a nasal sound such as the nasal stops /m, $\mathrm{n}, \mathrm{y} /$.

Vowels are characteristically oral as they are produced with a raised velum. However, vowels are nasalized if the soft palate is lowered to allow part of the airstream to escape through the nose. According to Ladefoged (1971, p. 33), nasalization of approximants, fricatives, and laterals occur only where one of the adjacent vowels is also nasalized, and there are allophonic variations, as vowels are nasalized to a greater or lesser extent in accordance with the nature of the adjacent consonants. Again, according to Ladefoged and Maddieson (1996, pp. 134, 268), contextual nasalization can lead to the addition of nasal vowel phonemes to a language.

Donwa-Ifode (1995, p. 43) also noted that vowels are usually nasalized when they occur in the environment of nasal consonants as in English [mæn] "man" and [hen] "hen", and that in some African languages, nasalization is clearer when the vowel occurs after the nasal consonant and not before it.

In Izọn, as in Akan and Edo, nasalization is distinctive, because it brings about a change in meaning as in Examples (1)-(6) in Table 3.

Table 3

Table Showing That Nasalization Is Distinctive in Izon (Yul-Ifode, 1999, p. 147)

\begin{tabular}{|c|c|c|}
\hline İọn & Akan & Edo \\
\hline Example (1) /su/ "fight"; /sũ/ "to stretch" & Example (2) /sa/ "cut"; /sã/"tie" & Example (3) /ti/ "be fat" / til/ "fly" \\
\hline Example (4) /bou/ “soft”; /bõ̃̃) "honey” & Example (5) /se/ "say"; /sẽ/ "hang about" & Example (6) /su/ "lead"; /sũ/ "crawl" \\
\hline
\end{tabular}

Emenanjo (1978), and B. M. Mbah and E. E. Mbah (2010) had also discussed the phenomenon of nasalization and assimilation in Igbo.

\section{The Present Perfect Tense in English}

In English, the present perfect tense denotes action or state of being that is completed at the time of speaking or writing, or that is continuing into the present. The present perfect tense is formed by combining the auxiliary have or has with the past participle form of a main verb. Semmelmeyer and Bolander (1981, pp. 149-150) (see Examples 7-8).

Example (7) I have studied in Port Harcourt for 10 years.

Example (8) I have taught two part-time classes since last year.

Ndimele (1996, pp. 84-85) said the present perfect tense is used to show that an action which took place in the past is still relevant in the present. 
Christophersen and Sandved (1969) were of the view that "tense is a set of grammatical forms bearing some relation to the notional category of time" (p. 220). They only recognized two tenses in English, viz. the "present" (or "non-past") and the "past". To them, "whereas the past tense reports a past action without any reference to the present moment, the perfect links up a past event with the present (time)" (p. 220). It can either denote an event which began in the past and which has continued right up to the present moment, as in Example (9).

Example (9) They have studied in Port Harcourt for three years (and are still studying there).

Or it can represent the present state of affairs as the result of an action or actions that took place in the past, as in Example (10).

Example (10) John and his wife have moved to Uyo (and as a result they are no longer living here in Yenagoa).

Nkwocha's (2008, p. 134) view is that the present perfect tense is used to state an action that began in the past up till the present and an action seen as completed in the present (see Example 11).

Example (11) Aliya has been sick since last week.

Eka (2004, p. 103) called the present perfect in which the effect of the past action or state is still felt in the present (e.g., has taken), the past in present.

Williamson (1991, pp. 149-150) observed that in İọn, the simple past is marked by zero in Bumọ, and by - $m i$ in Kolokuma and other dialects, while the immediate past (in which the effect of the past action or state is still felt in the present) is marked by a suffix -dẹ, dou, etc.

In Tarakiri, the simple past is marked by a suffix $-m i$, while the immediate past (in which the effect of the past action or state is still felt in the present) is marked by a suffix -de (see Examples 12-13).

Example (12) Eremá bodẹ. "The woman has come".

Example (13) Fịyaị mị akụ́dẹ́. "The soup has become bitter”.

\section{Assimilation in İọ̣n}

Assimilation is a natural phonological process whereby sounds become more similar to each other in terms of some of the feature values. Assimilation processes involving both oral and nasal segments abound in İọn. For example in İọn, the front vowel, /i/ assimilates to the backness of $/ \mathrm{gh} / \mathrm{in}$ the environment before a back consonant. In phonological terms, the high front vowel, $/ \mathrm{i} /$ rewrites as the high back vowel, $/ \mathrm{u} /$ in the environment before a high back consonant/gh/ (see Examples 14-15).

Example (14) ebi "good" ebugha "not good". /i/ rewrites as /u/ in "ebugha" before a high back consonant/gh/.

Example (15) mu "go" mugha "did not go". Here, /u/ in $m u$ is a back vowel and does not assimilate.

Example (16) E aka soro gha (fa)? (DS 1) Yé áká sộrọ ghá (fá)? (DS 2)

Y’áká sớrọ́ ghá (fá)? (SS) Won’t you wash (brush) your teeth?

Example (17) E akị gha (fa)? (DS 1) Yé ákị ghá (fá)? (DS 2)

Y'ákị ghá (fá)? (SS) Won’t you take (it)?

Example (18) E obori ba gha (fa)? (DS 1) Yé óbórí bá ghá (fá)? (DS 2)

Y'óbórí bá ghá (fá)? (SS) Won’t I slaughter a goat?

In the case of the phonological process in İọn of the replacement of an oral stop by a nasal stop after a syllable consisting of a nasal consonant or a nasalized vowel, the preceding nasal consonant or nasalized vowel is 
the conditioning sound, while the syllable-initial consonant in the syllable that follows which changes to become a nasal is the assimilated sound (see Examples 16-18).

In terms of direction of assimilation, this assimilation is progressive because the assimilated sound occurs after the conditioning sound. Formalized, the sequence is CA where "C" stands for the conditioning sound while "A" stands for the assimilated sound.

In terms of contiguity, sometimes, the conditioning segment and the assimilated segment occur next to each other (see Examples 24, 25, 26, 27, 27, 30, 34, 34, 37, and 39), i.e., they are not separated by any other segment, while in other instances they are non-contiguous (i.e., separated by some other segment) and the assimilation has to work across intervening segments and syllable boundaries.

In terms of extent of assimilation, here, the assimilation may be complete as when the assimilated sound takes over all the values of the features of the conditioning segment, but at other times the assimilation may be partial because the assimilated sound takes over only one (e.g., the place of articulation) or some, but not all the values of the features of the conditioning segment.

Just as vowels can be nasalized, consonants can also be nasalized. All the cases in this phonological process of the replacement of an oral stop /d/ by a nasal stop /n/ after a syllable consisting of a nasal consonant or a nasalized vowel, are those of consonant assimilation.

Many homorganic nasals are found in West African languages. Some examples in İọn include (see Examples 19-23):

$\begin{array}{ll}\text { Example (19) ombú } & \text { "navel” } \\ \text { Example (20) angọ́ } & \text { "body/self" } \\ \text { Example (21) ụndụ́ } & \text { "life" } \\ \text { Example (22) amba } & \text { "intestines" } \\ \text { Example (23) anda } & \text { "wrestle", etc. }\end{array}$

In İzọn, /d/ and /n/ are both alveolar stops. /d/ is an oral voiced alveolar plosive while $/ \mathrm{n} /$ is an (voiced) alveolar nasal. The two consonants (/d/ and /n/) are homorganic in İọn because they are made at the same place of articulation and with the same articulators. The present perfect tense is represented by the suffix, -de in the Tarakiri dialect of İọn. This -dẹ changes to -nẹ after a main verb which ends with a syllable that consists of a nasal consonant or a nasalized vowel. That is, in phonological terms, /d/ rewrites as $/ \mathrm{n} /$ in the environment after a syllable consisting of a nasal consonant or a nasalized vowel, i.e., $[+$ voice + alveolar + plosive $] \rightarrow[+$ alveolar + nasal] after [+ nasal].

A list of the verbs in Izọn (with their translations in English) in which this nasal assimilation occurs are as follows (see Examples 24-39):

$\begin{array}{lll}\text { Example (24) afịn } & \text { afịnnẹ } & \text { "has or have swept" } \\ \text { Example (25) baịn } & \text { baịnnẹ } & \text { "has run/fled" } \\ \text { Example (26) dan } & \text { dannẹ } & \text { "has stepped on" } \\ \text { Example (27) efín } & \text { efínnẹ́ } & \text { "has flown" } \\ \text { Example (28) famọ́ } & \text { famọ́nẹ́ } & \text { "has lost" } \\ \text { Example (29) ganrịn } & \text { ganrịnnẹ́ } & \text { "has become expensive” (phrasal verb?) } \\ \text { Example (30) kán } & \text { kánnẹ́ } & \text { "has torn" }\end{array}$




$\begin{array}{lll}\text { Example (31) limọ́ } & \text { limọ́nẹ } & \text { "has rid/killed" or "has erased/deleted" } \\ \text { Example (32) mị́ẹ́ } & \text { mị́nẹ } & \text { "has done/made" } \\ \text { Example (33) na } & \text { nanẹ } & \text { "has heard" } \\ \text { Example (34) owéín } & \text { owéínnẹ } & \text { "has bitten" } \\ \text { Example (35) pamọ́ } & \text { pamọ́nẹ } & \text { "has befallen" } \\ \text { Example (36) sáán } & \text { sáánnẹ́ } & \text { "has ground" } \\ \text { Example (37) tein } & \text { teinnẹ } & \text { "has shot" } \\ \text { Example (38) wáímọ́ } & \text { wáịmọ́nẹ } & \text { "has returned" (something) } \\ \text { Example (39) yanrịn } & \text { yanrịnnẹ } & \text { "has shaken" }\end{array}$

The following are examples of short sentences in which this nasal assimilation of İọn verbs occurs (see Examples 40-45):

Example (40) O munẹ. instead of O mudẹ.

He go has

He has gone.

Example (41) E sáánnẹ. $\quad$ instead of E sáándẹe.

I urinated have.

I have urinated.

Example (42) A báinnẹ́. instead of A báindẹ.

She run has

She has run.

Example (43) E sinnẹ. instead of E sindẹ.

I vomitted have

I have vomitted.

Example (44) O Yenagoa eyerin-nẹ instead of O Yenagoa eyerin-dẹ

He Yenagoa lived has

He has lived in Yenagoa.

Example (45) Egberi binnẹ. instead of Egberi bindẹ.

Stories many have become

Stories have become many.

In all the above examples, the initial consonant /d-/ of the present perfect tense marker [-de] after the main verb becomes a nasal $/ \mathrm{n}-/$.

It is worthy of note here that even borrowed English words obey this nasal assimilation rule as exemplified by the following examples (see Examples 46-47):

$\begin{array}{lll}\text { Example (46) bígíní } & \text { bígínínẹ́ } & \text { "has begun" } \\ \text { Example (47) sítatí } & \text { sítátídẹ } & \text { "has started" }\end{array}$

The verbs "begin" and "start" are represented by "koro" which is both a main verb "fall" and an auxiliary verb in Ịzọn.

The verb "bring" represented by "kọn bo" which means "take + come" consists of two main verbs in Izọn and as such is not affected by this nasal assimilation rule as the syllable "bo" does not contain a nasal. 
The nasal assimilation rule concerning the present perfect tense suffix -dẹ is neutralized in Izọn in the following verbs (see Examples 48-63):

\begin{tabular}{|c|c|c|}
\hline Example (48) arẹ & arẹ́dẹ́ & "has or have seen/beheld/found" \\
\hline Example (49) bá & bádẹ & "has killed/slain/(also) smitten" \\
\hline Example (50) dáwáí & dáwáídẹ & "has dreamt" \\
\hline Example (51) ekpárị & ekpárịdẹ & "has dried" \\
\hline Example (52) fa & fadẹ & "has finished" \\
\hline Example (53) gbá & gbádẹ & "has said/told" \\
\hline Example (54) káị & káị́dẹ & "has shut" \\
\hline Example (55) máálá & mááládẹ & "has wrapped" \\
\hline Example (56) obéi & obéídẹ & "has bent (down)" \\
\hline Example (57) páá & páádẹ́ & "has gone out" \\
\hline Example (58) sẹ́í & sẹ́ídẹ & "has danced" \\
\hline Example (59) tángbei & tángbeidẹ & "has lost" \\
\hline Example (60) vứrọ́ & vứrọ́dẹ & "has beaten" \\
\hline Example (61) wásáị & wásáị́dẹ & "has spread/dismissed", e.g., market \\
\hline Example (62) yẹrị & yẹrịdẹ & "has sold" \\
\hline Example (63) zi & zidẹ & "has given birth" \\
\hline
\end{tabular}

Below are examples of short sentences in which the nasal assimilation of İọn verbs under discussion does not occur, as both verbs yộu and bó end in oral vowels (see Examples 64-65):

Example (64) Ó yộụ́dẹ́

He travel has

He has travelled.

O yoụde remains the same. It does not change. We also say:

Example (65) Ó bódẹ́

He come has

He has come.

In this case, the initial consonant (d-) of the present perfect tense marker (-de) after the main verb does not become a nasal (n-) after the main verb.

\section{Summary}

All the cases in this phonological process of the replacement of an oral stop by a nasal stop $/ \mathrm{n} /$ after a syllable consisting of a nasal consonant or a nasalized vowel are those of consonant assimilation involving the assimilation of one consonant $/ \mathrm{d} /$ to another $/ \mathrm{n} /$, in the formation of the present perfect in İzọn.

In many verbs, whose present perfect tenses are represented by -dẹ in the Tarakiri dialect of Ịzọn, the [-dẹ] is changed to [-ne] after the main verb. In phonological terms, $/ \mathrm{d} /$ rewrites as $/ \mathrm{n} /$ in the environment after a syllable consisting of a nasal consonant or a nasalized vowel, i.e., $[+$ voice + alveolar + plosive $] \rightarrow[+$ alveolar + nasal $]$ after [+ nasal]. This paper looks at, describes, and examines this phonological process/phenomenon of the replacement of an oral stop by a nasal stop after a syllable consisting of a nasal consonant or a nasalized vowel. 


\section{Conclusions}

Nasals with assimilatory influence on neighbouring segments nasalize the vowel, leading to the presence of significantly nasalized vowels which contrast with their oral counterparts in İọn.

Nasal assimilation in Ịzọn may be contiguous when the assimilating (i.e., conditioning) and assimilated segment occur side by side, e.g., baịne, or non-contiguous when the assimilating and assimilated segments are separated by some other segment(s), e.g., mudẹ $\rightarrow$ munẹ.

Nasal assimilation in İọn may also be complete when the assimilated sound takes over all the features of the assimilating (i.e., conditioning) nasal as in bainne, or partial when the assimilated sound takes over some but not all the values of the features of the assimilating nasal.

\section{References}

Agbegha, C. B., Prezi, G. T., Tarilayefa, K., \& Prezi, A. (2011). Unified standard orthography for Ijo languages. Cape Town: Center for Advanced Studies of African Societies.

Atóyèbí, J. D. (1999). On nasals and nasalization in Òkọ. Retrieved from http://www.lingref.com/cpp/acal/39/paper2192.pdf

Childs, G. T. (2000). Nasality in Kisi. Retrieved from www.journalofwestafricanlanguages

Christophersen, P., \& Sandved, A. O. (1969). An advanced English grammar. London: The Macmillan Press Limited.

Donwa-Ifode, S. (1995). Basic phonetics. Port Harcourt: Sunray Books Publications Limited.

Eka, D. (2004). Elements of grammar and mechanics of the English language. Uyo: Samuf (Nig.) Ltd..

Emenanjo, E. N. (1978). Elements of modern Igbo grammar. Ibadan: Oxford University Press.

Ladefoged, P. (1971). Preliminaries to linguistic phonetics. Chicago and London: University of Chicago Press.

Ladefoged, P. (1975). A course in phonetics. New York: Harcourt Brace Jovanovich, Inc..

Ladefoged, P., \& Maddieson, I. (1996). The sounds of the world's languages. Oxford: Blackwell.

Mbah, B. M., \& Mbah, E. E. (2010). Topics in phonetics and phonology. Nsukka: AP Express Publishers.

Ndimele, O.-m. (1996). An advanced English grammar \& usage. Aba: National Institute for Nigerian Languages.

Nkwocha, C. R. (2008). Essentials of English language. Onitsha: Africana First Publishers PLC.

Roach, P. (2000). English phonetics and phonology. Cambridge: Cambridge University Press.

Semmelmeyer, M., \& Bolander, D. O. (1981). Instant English handbook. New Jersey: Career Publishing, Inc..

Williamson, K. (1973). More on nasals and nasalization in Kwa. Studies in African Linguistics, 4(2), 115-138.

Williamson, K. (1991). The tense system of İzọn. In E. E. Okon (Ed.), The tense systems of Nigerian languages and English.

Cologne: Afrikanistische Arbeitspapiere AAP No. 27.

Yul-Ifode, S. (1999). A course in phonology (pp. 212-229). Port Harcourt: Riverside Communication. 